universities and their libraries, all library schools, all library organizations, all higher education organizations, and all agencies which accredit academic institutions.

3. Investigate all violations of these standards which are reported by members of the Association of College and Research Libraries. Such investigations will be coordinated and supervised by the Committee on Academic Status of the Association of College and Research Libraries.

4. Invoke the following sanctions against institutions of higher education which are found, after such investigation, to be in violation of any or all of these standards:

a. Publicize the violation and the institution concerned in CRL News and other appropriate publications. b. Refuse to accept advertisements in any ALA publication for positions at that institution.

c. Discourage its members from accepting employment at that institution, through notices in its publications and other means.

A reasonable amount of time-three to five years-should be provided college and university libraries which do not currently conform to any or all of these standards, to enable them to do so. However, no such grace period should be provided to libraries which currently do conform, either wholly or in part, and which seek to deny or withdraw any such rights and privileges.

\title{
Norman Tanis Elected Vice President
}

Norman E. Tanis, director of University Libraries at California State University, Northridge, is the newly elected vice-president of the Association of College and Research Libraries. Tanis received a total of 1,849 votes in the elections held late this spring. Richard Ducote, director for Instructural Resources at the College of DuPage, Glen Ellyn, Illinois, polled 1,081 votes. Both Tanis and Ducote have long been interested in and associated with twoyear colleges and their nominations recognized the increasing importance of junior and community college librarians in ACRL.

After obtaining a Master of Arts in Library Science and an M.A. in history from the University of Michigan, Tanis became reference librarian and later head librarian at Henry Ford Community College, Dearborn, Michigan. From 1966 through 1969 he held the position of director of libraries and professor of $\mathrm{Li}$ brary Science at Kansas State College, Pittsburgh, Kansas. He has been at California State University, Northridge, formerly known as San Fernando Valley State College, since 1969.

Tanis received his undergraduate training at Calvin College. In addition to his other degrees from the University of Michigan he was awarded an M.A. in education from that institution in 1961. Tanis has been a member of the ACRL Board of Directors since 1967. He also served in this capacity from 1962 to 1965 . $\mathrm{He}$ has been chairman of the Junior College Libraries Section, chairman of the Committee on Standards and Accreditation, a member of the Editorial Board of College \& Research Libraries, and a member of the ACRL-Asso- ciation of Research Libraries Joint Committee on University Libraries Standards. He has also held positions on various ALA committees and has been an ALA representative to other educational and professional organizations.

As vice-president Tanis will serve as a member of the New York Conference Planning Committee, a member of the ALA Budget Assembly, and chairman of the ACRL Planning Committee. He will become ACRL's thirty-fifth president at the close of the Las Vegas Conference in June of 1973.

The results of the section and subsection elections are as follows: (Elected officers are shown in italics.)

\section{COLLEGE LIBRARIES SECTION}

Vice Chairman/Chairman-Elect: Father Jovian Lang, librarian, University of South Florida, Tampa, Florida (385); Richard C. Quick, director of libraries, State University of New York, College of Arts and Science, Geneseo, New York (514). Secretary: Carol C. Henderson, reference and circulation librarian, George Mason College of the University of Virginia, Fairfax, Virginia (388); Beverly M. Johnson, chairman, Catalog Department, San Diego State University, San Diego, California (487).

\section{JUNIOR COLLEGE LIBRARIES SECTION}

Vice Chairman/Chairman-Elect: Louise Giles, dean of Learning Resources, Macomb County Community College, Warren, Michigan (279); W. Christian Sizemore, acting academic dean, South Georgia College, Douglas, 
Georgia (107). Secretary: Jo Ellen Flagg, librarian, Forest Park Community College, St. Louis, Missouri (180); Rosemary Henderson, director of Library Services, Coffeyville Community Junior College, Coffeyville, Kansas (190).

\section{RARE BOOKS SECTION}

Vice Chairman/Chairman-Elect: Ruth Salisbury, rare book librarian, George Arents Research Library, Syracuse University, Syracuse, New York (285); Evert Volkersz, special collections librarian, State University of New York at Stony Brook, Stony Brook, New York (148). Member-at-large: D. W. Krummel, professor of Library Science, University of Illinois, Graduate School of Library Science, Urbana, Illinois (214); Richard S. Wormser, rare books dealer, Bethel, Connecticut (223).

\section{SUBJECT SPECIALISTS SECTION*}

Vice Chairman/Chairman-Elect: Wayne Gossage, director of Library Services, Bank Street College of Education Library, New York, New York (330); Louis A. Jacob, head, Southern Asia Section, Orientalia Division, Library of Congress, Washington, D.C. (495).

\section{Agriculture and Biological}

Sciences Subsection *

Vice Chairman/Chairman-Elect: Richard A. Farley, director of libraries, Kansas State University, Manhattan, Kansas (116); Sharon Wells, assistant librarian, Bibliographic Services Section, Archive Library Department, American Medical Association, Chicago, Illinois (87). Secretary: Epsy Y. Hendricks, head librarian, Alcorn A\&M College, Lorman, Mississippi (59); Ann Kerker, professor of Library Science and Veterinary Medical librarian, Purdue University, Lafayette, Indiana (139).

\section{Art Subsection*}

Vice Chairman/Chairman-Elect: William R. Johnson, chief, Art and Music, Brooklyn Public Library, Brooklyn, New York (99); Barbara Sevy, librarian, Philadelphia Museum of Art Library, Philadelphia, Pennsylvania (127).

\section{Asian and North Afrucan Subsection *}

Vice Chairman/Chairman-Elect: Juanita S. Doares, chief of Acquisition Division, New York Public Library, New York, New York (53); Om. P. Sharma, head, South Asia Division, University of Michigan Library, Ann Arbor, Michigan (92). Member-at-large: Edward A. Jajko, Near East bibliographer-cataloger, Yale University Library, New Haven, Connecticut (76); Alice N. Loranth, head, John G. White Department of Orientalia, Folklore, and Chess, Cleveland Public Library, Cleveland, Ohio (64).
Education and Behavional Sciences SUBSECTION*

Vice Chairman/Chairman-Elect: Priscilla Linsley, librarian, Educational Testing Service, Princeton, New Jersey (130); Lorraine Mathies, head, Educational and Psychology Library, special consultant, ERIC Clearinghouse for Junior Colleges, University of California, Los Angeles, California (205).

\section{Law and Political Science}

Subsection ${ }^{*}$

Vice Chairman/Chairman-Elect: Nancy Rodgers, Hempstead, New York (147); Michael O. Shannon, assistant professor and documents librarian, Herbert Lehman College, Bronx, New York (103). Member-at-large: Jennie Cross, documents librarian, Oakland University, Rochester, Michigan (117); Nancy K. Smith, librarian, Fels Center of Government, University of Pennsylvania, Philadelphia, Pennsylvania (128).

\section{Slavic and East European SUBSECTION *}

Vice Chairman/Chairman-Elect: Vasyl Luchkiw, director of Library Services, Rockland Community College Library, Suffern, New York (55); Ray R. Suput, director of the University Library, Ball State University, Muncie, Indiana (70). Secretary: Stan Humenuk, head catalog librarian, Western Illinois University, Macomb, Illinois (106). Member-at-large: William Putnam, research associate, Association of Research Libraries, Slavic Bibliographic and Documentation Center, Washington, D.C. (75); Wasyl Sirskyj, Slavic cataloger, Waterloo, Ontario, Canada (51).

\section{UNIVERSITY LIBRARIES SECTION}

Vice Chairman/Chairman-Elect: J. Richard Blanchard, University Librarian, University of California, Davis, California (817); Richard W. Boss, director of libraries, University of Tennessee, Knoxville, Tennessee (688).

By action of the Board of Directors on June 29, 1972 the Subject Specialist Section of ACRL was eliminated and the subsections were given sectional status. Louis A. Jacob, recently elected vice chairman of the SSS, will therefore not take office.
ACRL Membership
June 30,1972
11,666
June 30,1971
June 30,1970 